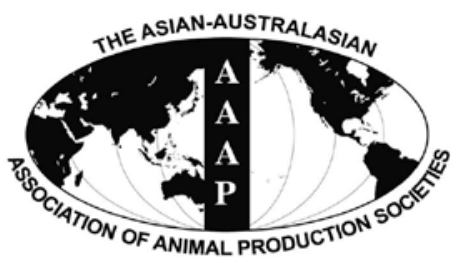

Asian-Aust. J. Anim. Sci.

Vol. 25, No. 1 : 37 - 43

January 2012

www.ajas.info

http://dx.doi.org/10.5713/ajas.2011.11139

\title{
Melatonin Induced Changes in Specific Growth Rate, Gonadal Maturity, Lipid and Protein Production in Nile Tilapia Oreochromis niloticus (Linnaeus 1758)
}

\author{
Ruchi Singh, A. K. Singh* and Madhu Tripathi ${ }^{1}$ \\ National Bureau of Fish Genetic Resources, Canal Ring Road, \\ P. O. Dilkusha, Lucknow-226002, Uttar Pradesh, India
}

\begin{abstract}
We have investigated the effect of melatonin (MLT) on specific growth rate (SGR\% day ${ }^{-1}$ ), condition factor $(\mathrm{k}$ ), gonado-somatic-index (GSI), histological structures of gonads, serum as well as gonadal protein and lipid in Nile tilapia Oreochromis niloticus. MLT treatment in the dose of $25 \mu \mathrm{g} / \mathrm{L}$ for three weeks reduced SGR\% day ${ }^{-1}(0.9 \pm 0.04)$ as compared to control (1.23 \pm 0.026$)$. The GSI value was significantly $(\mathrm{p}<0.05)$ reduced to $1.77 \pm 0.253$ from control where it was $2.56 \pm 0.25$. Serum protein level increased from $9.33 \pm 2.90 \mathrm{mg} / \mathrm{ml}$ (control) to $11.67 \pm 1.45 \mathrm{mg} / \mathrm{ml}$ after MLT treatment while there was depressed serum triglycerides (86.16 \pm 1.078 $\mathrm{mg} / \mathrm{dl})$ and cholesterol $(126.66 \pm 0.88 \mathrm{mg} / \mathrm{dl})$ as compared to control values where these were $123.0 \pm 1.23 \mathrm{mg} / \mathrm{dl} \mathrm{and} 132.0 \pm 1.65 \mathrm{mg} / \mathrm{dl}$ respectively. Histological structure of ovary showed small eggs of early perinucleolus stage after MLT treatment while testicular structure of control and MLT treated fish was more or less similar. It is concluded that exogenous melatonin suppressed SGR\% day ${ }^{-1}$, GSI, ovarian cellular activity, protein and lipid biosynthesis, in tilapia suggesting that melatonin is useful in manipulating the gonadal maturity in fishes. (Key Words : Melatonin, Gonad Structure, GSI, Condition Factor, SGR\%, Biochemical Changes, Oreochromis niloticus)
\end{abstract}

\section{INTRODUCTION}

Melatonin, the hormone synthesized by the pineal organ in fish mainly, was first isolated from beef pineal organs (Lemer et al., 1958) and is chemically known as N-acetyl-5methoxytryptamine. It is a naturally occurring compound found in animals, plants, and microbes, (Caniato et al., 2003) and it has been described to influence feeding and locomotory rhythms (Pinillos et al., 2001; Zhdanova et al., 2001), as well as glucose homeostasis in fish (Delahunty and Tomlinson, 1984). In addition, it has also been found as a potent antioxidant, in recent years (Reiter et al., 2000; Boutin et al., 2005). In vertebrates, circulating levels of melatonin vary in a diurnal cycle, thereby regulating the circadian rhythms of several biological functions (Altun and Ugur-Altun, 2007; Paredes, 2009). In mammals, the photoperiodic message is reported to be mediated via

\footnotetext{
* Corresponding Author: A. K. Singh. Tel: +91-522-2442440, Fax:+91-522-2442403, E-mail: aksingh56@rediffmail.com

1 Department of Zoology, University of Lucknow, Lucknow226010, Uttar Pradesh, India.

Received May 16, 2011; Accepted July 28, 2011
}

melatonin, but it is unclear whether this also applies to fish as well (Bromage et al., 1995). Administration of melatonin has been reported to mimic a short non-stimulatory photoperiod cycle and to influence maturation in male three-spined sticklebacks Gasterosteus aculeatus, kept under stimulatory long photoperiods (Bornestaf et al., 2001). The fact that lighting influences fish reproduction, has been exploited in aquaculture, where artificial lights have been used to submit fishes to shorter or longer day lengths, and thus managed to advance or delay gonad maturation or spawning time (Bromage et al., 1995). Experimental evidences indicate that the pineal organ and/or melatonin control seasonal maturation of gonads in fish (Bromage et al., 2001; Maitra et al., 2001; Bayarri et al., 2004). Melatonin-treated Rana ridibunda maintained on a long photoperiod (18 L:6 D) produced significantly smaller gonads than control animals. Frogs injected daily with melatonin exhibited a substantial decrease in ovarian weight when compared to saline-injected animals (Delgado et al., 1983).

Earlier workers have demonstrated the influence of melatonin on the action of maturation inducing hormone 
(MIH) thereby affecting the maturation of oocytes in carps (Chattoraj et al., 2005). Ghosh and Nath (2005) have shown that melatonin is effective in inhibiting ovarian vitellogenesis, plasma GtH II levels, and gonado-somatic-index (GSI) in a catfish, Clarias batrachus. Melatonin also, influences the inhibition of hypothalamic dopamine secretion in common carp (Popek et al., 2006). The fish pineal, through the cyclical synthesis and release of melatonin, seems to be involved in the control of reproduction (Joy and Agha, 1991; Vanecek, 1998; Bromage et al., 2001). It is reported that rhythmical secretion of melatonin by the pineal gland subsequently induces physiological, metabolic and gonadal changes in fish (Koger et al., 1999; Porter et al., 1999; Bromage et al., 2001; Oppedal et al., 2001, 2003). Experimental evidences indicate that the pineal organ and/or melatonin control maturation of gonads in fish (Bromage et al., 2001; Maitra et al., 2001; Bayarri et al., 2004) and also in sex change in tilapia (Singh, 2009) and rice field eel (Shi Qiong, 2005). In view of the above facts, the present study was undertaken to assess the effect of melatonin on fish growth, gonadosomatic index, maturity of gonad, total gonadal protein and lipid in Nile tilapia Oreochromis niloticus (Linnaeus, 1758). The result of this study will be useful to enhance knowledge on the role of melatonin in fish reproduction.

\section{MATERIALS AND METHODS}

300 live fish specimens of Nile tilapia Oreochromis niloticus weighing $2.8 \pm 1.58 \mathrm{~g}$ and measuring $3.14 \pm 1.22 \mathrm{~cm}$ was procured and acclimatized to laboratory conditions (12: $12 \mathrm{~h}$ L:D condition) in glass aquaria (300 L capacity) for two weeks prior to their use in the experimental study. Fishes were fed twice a day with commercially available granulated food (Taiyo Pet Productions Pvt. Ltd.) which contained fish meal, wheat flour, soybean meal, corn meal, yeast, vitamins and minerals. The nutritional content of the feed was $32 \%$ crude protein, $4 \%$ crude fat, $5 \%$ crude fiber and $10 \%$ moisture. In addition to feeding with granules, fishes were also fed with planktons collected from the fish farm of the institute, once daily at noon to keep them healthy and to enable fishes to attain maturity. All the fish were divided into two groups and maintained them in glass aquaria in replicates. The first group received melatonin (Sigma Chemicals Co., USA) in the dose of $25 \mu \mathrm{g} / \mathrm{L}$ through rearing water under normal photoperiod for three weeks. The control group of fishes was held in normal day night condition on similar diet but without MLT treatment to rearing water. The water parameter of keeping tank during experiment was maintained at $25.5 \pm 2^{\circ} \mathrm{C}$ temperature, $7.2 \mathrm{pH}$ and 4.8-5.2 mg/L dissolved oxygen.

\section{Somatic and gonadal growth}

Length and weight $\left(\mathrm{F}_{\mathrm{L}}\right.$ and $\left.\mathrm{F}_{\mathrm{W}}\right)$ of control and MLT treated fish was registered with the help of a digital caliper meter scale and a digital weighing machine (Denver Instrument) at the end of 21 day. Condition factor (k) was calculated as (weight in g)/(length in $\mathrm{cm})^{3} \times 100$ and specific growth rate (SGR \% day ${ }^{-1}$ ) was calculated as SGR $\left(\%\right.$ day $\left.^{-1}\right)$ $=100(\log$ final weight-log initial weight $) / \mathrm{n}$. Where, $\mathrm{n}=$ days of experiment. The GSI was determined as Gonad weight/body weight $\times 100$; The GSI was calculated with a precision of $0.01 \mathrm{~g}$ to show any changes in fish maturity.

\section{Biochemical analysis}

Both control as well as MLT treated fish was gently netted out the aquarium and five fishes from each experimental group was anesthetized by putting them in water containing $100 \mathrm{mg}$ tricaine-methane-sulfonate (MS222, Sigma Chemical Co., USA) per liter buffered with sodium bicarbonate1:1. Blood was drawn from the caudal fin of the anaesthetized fish and collected in heparinized tubes. About $2 \mathrm{ml}$ of the blood was centrifuged at 5,000 rpm for 5 minute and the plasma so obtained was used for analysis of protein (Lowry et al., 1951) using kit (Bangalore GENEI/ Qualigens). Similarly, the gonadal protein was also determined using $2 \mathrm{mg}$ gonadal tissue. Absorbance reading for protein was taken with Spectrophotometer (Tecan, USA) at an optical density of 660nm. For measurement of serum lipid, blood was collected into tubes containing $1 \mathrm{mg}$ $\mathrm{EDTA} / \mathrm{ml}$. Lipid extraction was done following the method of Bligh and Dyer (1959) by using a mixture of Chloroform and methanol (1:2) followed by a mixture of chloroform and water (1:1). Reading of lipid concentration was taken using a spectrophotometer (Tecan, USA) on $440 \mathrm{~nm}$. Similarly, gonads collected from the control as well as MLT treated fishes were also subjected to total lipid estimation by the same method. Triglycerides and cholesterol were estimated by the method described by Stein (1986).

\section{Histological examination}

Anesthetized fish used in biochemical studies were dissected after collecting blood and gonads were removed immediately afterwards and fixed in $10 \%$ natural buffer formalin solution, dehydrated in different grades (30\%, $70 \%, 90 \%$ and absolute) ethanol and embedded in paraffin wax. Sections (5-7 $\mu \mathrm{m}$ thick) were cut, dewaxed dehydrated with different grades of ethanol, stained with Haematoxylin and Eosin, dehydrated and mounted in Canada balsam (Merk, Darmstadt, Germany). Sections were examined under a compound microscope (Olympus Co., Japan).

\section{Statistical analysis}

All data were expressed as, mean \pm standard error mean $(\mathrm{X} \pm \mathrm{SEM})$. Data of all parameters were analyzed by one 


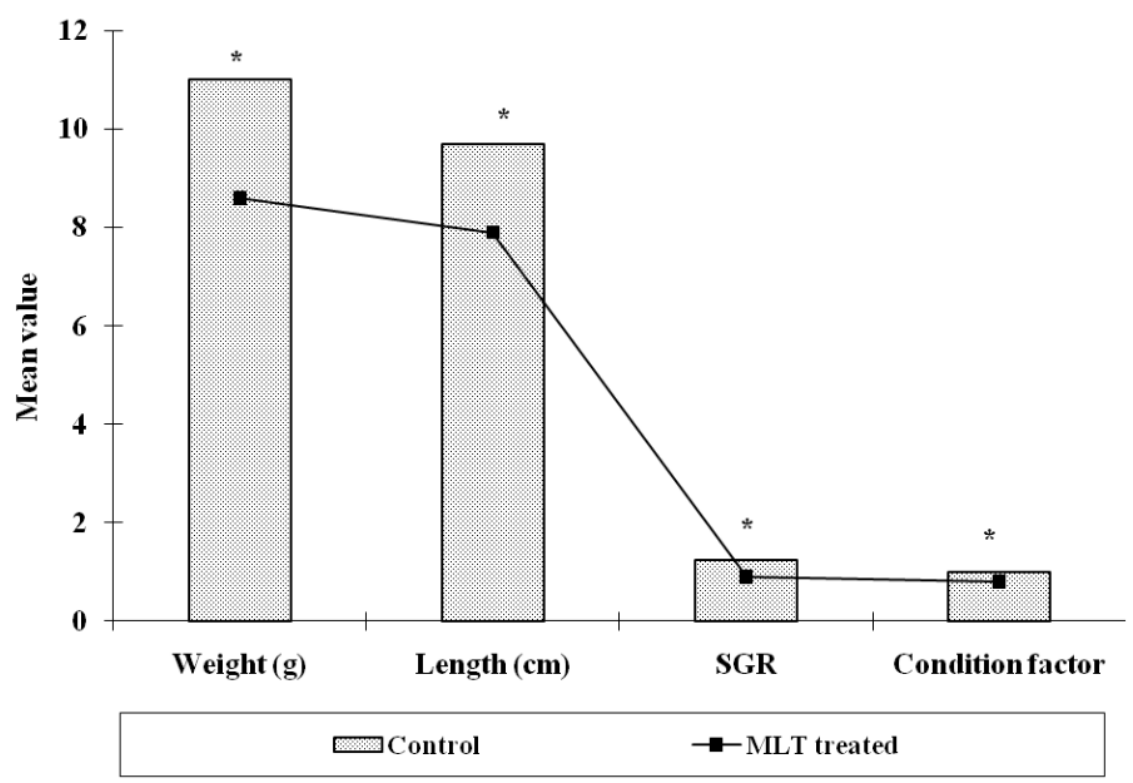

Figure 1. Effect of melatonin (MLT) treatment on physiological parameters (weight, length, SGR\% day ${ }^{-1}$ and condition factor) of O. niloticus (Significance level, $* \mathrm{p}<0.01$ ).

way analysis of variance (ANOVA) using a computer programmed software, Statistical Package for Social Science Version (SPSS)-10.0.

\section{RESULTS}

The experimental fishes were found healthy throughout the observation period and there was hardly any mortality in both the groups i.e., control and MLT treated fishes. The length and weight of fish of control group was $9.6 \pm 0.23 \mathrm{~cm}$ and $11.0 \pm 0.39 \mathrm{~g}$ respectively after three weeks. However, the weight of MLT treated fish reduced to 8.6 $\pm 0.47 \mathrm{~g}$ which was 78.18\% low as compared to control. The length of MLT treated fish also declined to7.9 $\pm 0.421 \mathrm{~cm}$ after the same period and there was $82.29 \%$ reduction (Figure 1). The specific growth rate (SGR \% day ${ }^{-1}$ ) when calculated was found to decline after MLT treatment and it was $0.9 \pm 0.04$ as compared to $1.23 \pm 0.02$ observed in control fishes (Figure 1). The calculated, condition factor $(\mathrm{k})$ was found to be $0.99 \pm 0.026$ in control group while it was $0.80 \pm 0.04$ in MLT treated fishes. The Ganado-somatic index (GSI) of control fish and MLT treated fish were found negatively correlated with each other, and the correlation coefficient (r) was -0.51 . The GSI value for control group of fishes was $2.56 \pm 0.25$

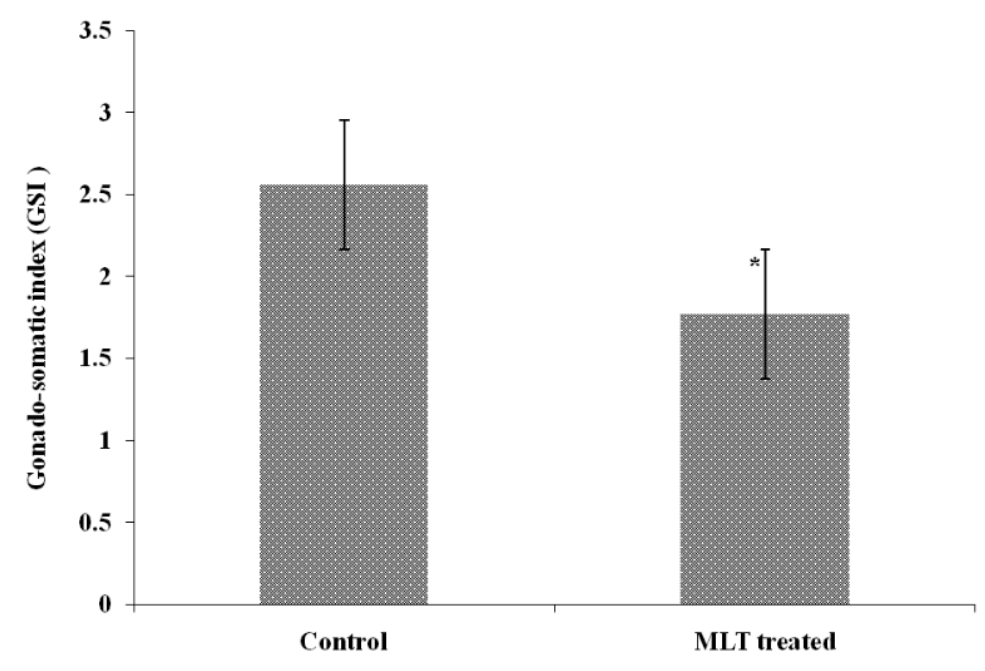

Figure 2. Effect of melatonin (MLT) on GSI of Oreochromis niloticus (Bar showing statistical difference between control and MLT treatment. Level of significance $* \mathrm{p}<0.05)$. 


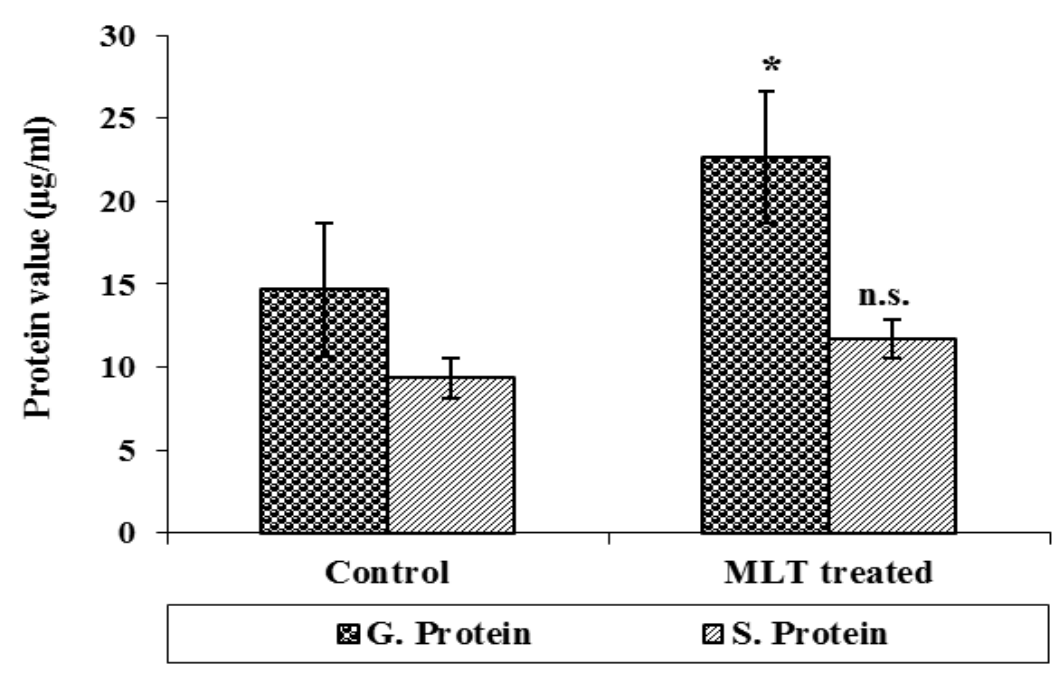

Figure 3. Serum protein and gonadal protein after melatonin (MLT) treatment to normal O. niloticus (n.s. = statistically not significant and * statistically significant $\mathrm{p}<0.01)$.

and $1.77 \pm 0.25$ in the MLT treated group after three weeks and it was significantly $(\mathrm{p}<0.05)$ lower in case of MLT treatment (Figure 2).

Total gonadal protein was $14.67 \pm 1.45 \mathrm{mg} / \mathrm{g}$ in control group and it significantly $(\mathrm{p}<0.01)$ increased to $22.67 \pm 0.66$ $\mathrm{mg} / \mathrm{g}$ after MLT treatment. Serum protein level however, increased after MLT treatment and it was $9.33 \pm 2.90 \mathrm{mg} / \mathrm{ml}$ in control group while in MLT treated fish it was 11.67 $\pm 1.45 \mathrm{mg} / \mathrm{ml}$ and the difference was insignificant (Figure 3). The serum cholesterol level in control group of fishes was $132.0 \pm 1.65 \mathrm{mg} / \mathrm{dl}$ which declined to $126.66 \pm 0.88 \mathrm{mg} / \mathrm{dl}$ after MLT treatment and was significant $(\mathrm{p}<0.01)$. Similarly, serum triglyceride level also declined significantly $(\mathrm{p}<0.001)$ from $123.0 \pm 1.23 \mathrm{mg} / \mathrm{dl}$ in the control group to

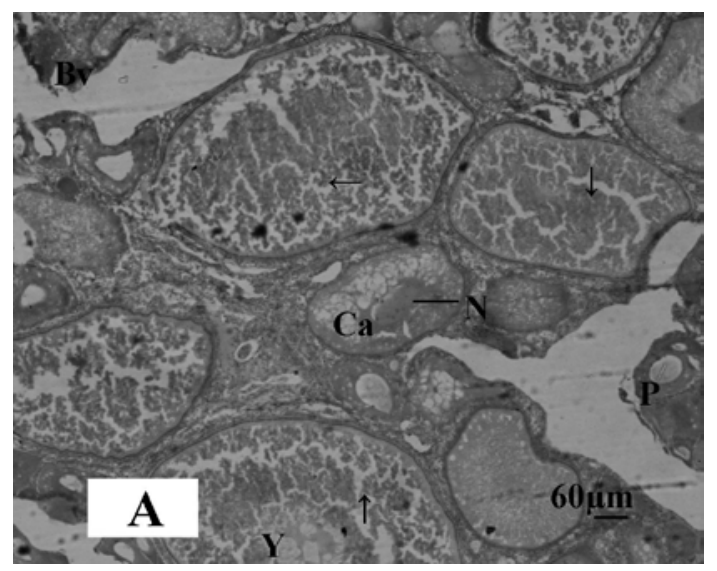

Microphotograph 1A. Histological section of ovary of control Oreochromis niloticus showing oocyte in the first growth phase $(\rightarrow)$, cortical alveolar cells (Ca), Perinucleaur cells (P), Blood vessels (Bv), Yolk bodies (Y), and Nucleolus of oocytes. Haematoxylin and Eosin, X- bar $60 \mu \mathrm{m}$.
$86.16 \pm 1.078 \mathrm{mg} / \mathrm{dl}$ in fishes exposed to MLT (Figure 4). The gonadal total lipid was found $1.05 \pm 0.01 \mu \mathrm{g} / \mathrm{g}$ in the control group of fishes which reduced significantly $(\mathrm{p}<0.05)$ to almost half and it was $0.50 \pm 0.20 \mu \mathrm{g} / \mathrm{g}$ after MLT treatment.

The gonadal development of $O$. niloticus was found asynchronous. In female, the oogonia contained a nucleus with a conspicuous nucleolus and a weak staining cytoplasm. The cortical alveloli were pushed in the periphery of the oocytes and most of the cytoplasm was filled with yolk globules (Microphotograph 1A). The histological observations of the ovary of MLT treated fish revealed suppressed developing stage of ovary. Small eggs were found in early perinucleolus stage. MLT treated fish

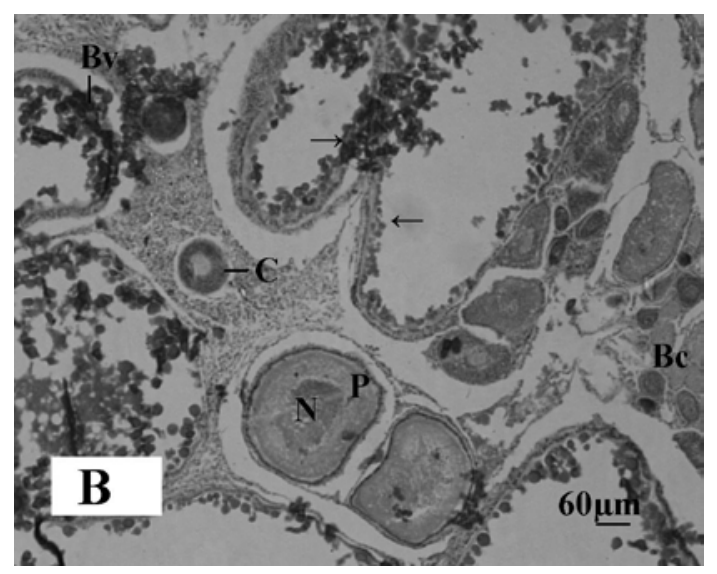

Microphotograph 1B. Histological section of the melatonin treated ovary of Oreochromis niloticus showing distribution of early perinuclear stage oocytes $(\rightarrow)$. Perinuclear cells $(\mathrm{P})$, Blood capillaries (Bc), Blood Vessels (Bv) and Cortex of ovary (C). Haematoxylin and Eosin, X- bar $60 \mu \mathrm{m}$. 


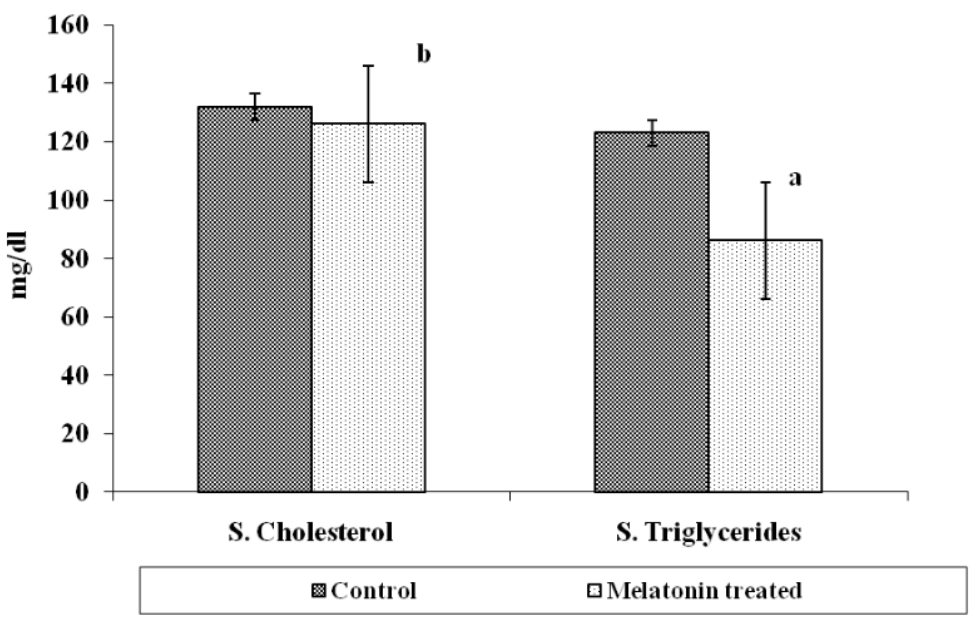

Figure 4. Serum cholesterol and serum triglycerides of $O$. niloticus after melatonin (MLT) treatment (significance level: 'a' $\mathrm{p}<0.001$, ' $\mathrm{b}$ ' $\mathrm{p}<0.01)$.

did not show maturing oocytes unlike control fish. In the MLT treated fish, ovary of $O$. niloticus showed deeply basophilic cytoplasm in follicular cells having nucleolus in nucleus (Microphotograph 1B). In male, each spermatogonium contained a large nucleus, a distinct nucleolus and a network of chromatin. MLT treatment to fish did not show any conspicuous changes in the testicular structure. Testicular development of controlled fish and MLT treated fish was more or less similar.

\section{DISCUSSION}

Results of this study indicated that continuous treatment of melatonin to fish inhibited somatic and gonadal growth in O. niloticus. The finding of this study revealed that MLT treatment suppressed length and weight of fish which supported the earlier report where melatonin in the dose of $10 \mu \mathrm{g} / \mathrm{g}$ body weight has been shown to reduce body weight of gold fish Carassius auratus (Lopez et al., 2006; De Pedro et al., 2008). The condition factor of MLT treated fish was a little lower in comparison to control fish in our study which suggested that MLT did not affect the performance of the fish. Our findings corroborated with earlier report where melatonin was found to affect the body mass and condition factor of Arctic charr, Salvelinus alpines (Aarseth et al., 2010).

Melatonin normally has been reported to decline protein level in blood and gonadal tissue in fish (Falcon et al., 2007). However, our findings indicated that protein level increased after MLT treatment. Information concerning the lipid and protein value in O. niloticus after MLT treatment is limited. Lipid was recognized as a major form of energy stored in teleosts during gonadogenesis. Shulman (1974) reported that, lipid stored in the body and viscera of teleost supplied the energy necessary for gonadal maturation. Total lipid level of fish was reduced by the administration of melatonin in Nile tilapia suggesting that low level of lipid might have negatively affected the gonadal development. Lipid peroxides, uric acid, blood glucose, total lipid, triglycerides and cholesterol have been reported to decline in fish as well as in rats after the oral administration of melatonin (Mamdouh and Abdel-Raheim, 2003). The results of this study delineated that melatonin regulated metabolic activity of protein and lipid in O. niloticus (Lopez et al., 2006).

The effect of MLT on gonadal development of $O$. niloticus suggested that melatonin exerted potential inhibitory effect on GSI and gonadal development. In many animals, melatonin has been reported to possess antigonadal effect (Sreenivasan et al., 2009). Numerous data suggest involvement of melatonin in reproductive physiology (Tamura et al., 2009). However, information about the role of melatonin in fish reproduction is still fragmentary (Guererro et al., 2007; Chattoraj et al., 2009a, b; Falcon et al., 2009a, b; Renuka and Joshi, 2010). Renuka and Joshi (2010) immersed Channa punctatus in water containing melatonin $(100 \mu \mathrm{g} / \mathrm{L})$ for 24 and 17 h daily and found that the GSI increased, but when the same dose was given by way of injection, GSI decreased. Melatonin has been reported to possess inhibitory effects in catfish Clarias batrachus (Ghosh and Nath, 2005) while MLT implants (18 $\mathrm{mg}$ ) in fish suppressed the gonadal maturation of turbot females three months after implantation (Alvaro et al., 2001). The result of this study provided evidences of inhibitory influences of exogenous melatonin on gonadal maturity in tilapia. The antigonadal effects of melatonin has also been reported in Oryzias latipes (Uraski, 1972), and Heteropneustes fossilis (Sundararaj and Keshavanath, 1976). The effect of MLT on the structure of ovary and ovarian cells was similar as reported earlier (Borg and Ekstrom, 
1981; Fatemet et al., 2007; Wang et al., 2008). The minimum employed dose of melatonin was $25 \mu \mathrm{g} / 100 \mathrm{~g}$ body weight/day, and this is frequently reported dose to study the effect of melatonin on the gonads (Maitra et al., 2005). Effect of melatonin on reproductive processes in fish, most often, points to its stimulatory or inhibitory effect depending on the species, season of the year, time of the day, and degree of sexual maturity, but fails to show how and where melatonin affects the reproductive system (Sokolowaska et al., 2004).

\section{CONCLUSION}

It is concluded that exogenous melatonin can change the biometrics, physiology and gonadal development of fish. The results obtained on the biometric parameters, biochemical data, GSI and gonadal structures demonstrated that melatonin is involved in a wide complex system that regulates growth, lipid and protein metabolism and reproduction in $O$. niloticus. However, the role of melatonin in the control of reproduction is still debatable as very little is known about the mechanism by which melatonin contributes to this process.

\section{ACKNOWLEDGEMENTS}

The authors are grateful to Dr J. K. Jena, the Director, NBFGR for his kind support, encouragement and providing all necessary facilities. Authors are thankful to Mr. Abubakar Ansari, Senior Research Fellow at NBFGR for his help in day to day monitoring of the experimental fishes and data collection.

\section{REFERENCES}

Aarseth, J. J., E. Froiland and E. H. Jorgensen. 2010. Melatonin implantation during spring and summer does not affect the seasonal rhythm of feeding in anadromous Arctic charr (Salvelinus alpines). Polar Biol. 33:379-388.

Altun, A. and B. Ugur-Altun. 2007. Melatonin: therapeutic and clinical utilization. Int. J. Clin. Pract. 61:835-845.

Alvaro, J. M. R., P. G. Rebollar, M. Olmedo, B. Alvarez-Blazquez, E. Ubilla and B. P. D. Peleterio. 2001. Effects of melatonin implants on reproduction and growth of turbot brood stock. Aquacult. Int. 9:477-487.

Bayarri, M. J., L. Rodriguez, S. Zanuy, J. A. Madrid, F. J. Sanchez-Vazquez, H. Kagawa, K. Okuzawa and M. Carrillo. 2004. Effects of photoperiod manipulation on the daily rhythms of melatonin and reproductive hormones in caged European sea bass Dicentrachus labrax. Gen. Comp. Endocrinol. 136:72-81.

Bligh, E. G. and W. J. Dyer. 1959. A rapid method of total lipid extraction and purification. Can. J. Biochem. Physiol. 37:911917.
Borg, B. and P. Ekstrom. 1981. Gonadal effects of Melatonin in the three-spined stickeleback, Gasterosteus aculeatus L., during different season and photoperiods. Reprod. Nutr. 21:919-927.

Bornestaf, C., I. Mayer and B. Borg. 2001. Melatonin and maturation pace in female three-spined stickleback, Gasterosteus aculeatus. Gen. Comp. Endocrinol. 122:341-348.

Boutin, J. A., V. Audinot, G. Ferry and P. Delagrange. 2005. Molecular tools to study melatonin pathways and actions. Trends Pharmacol. Sci. 26:412-419.

Bromage, N., M. Porter and C. Randall. 2001. The environmental regulation of maturation in farmed finfish with special reference to the role of photoperiod and melatonin. Aquaculture 197:63-98.

Bromage, N. R., C. F. Randall, M. J. R. Porter and B. Davies. 1995. How do photoperiod, the pineal, melatonin and circannual rhythms interact to coordinate seasonal reproduction in salmonid fish? Reprod. Physiol. 95:164-166.

Caniato, R., R. Filippini, A. Piovan, L. Puricelli, A. Borsarini and E. M. Cappelletti. 2003. Melatonin in plants. Adv. Exp. Med. Biol. 527:593-597.

Chattoraj, A., S. Bhattacharyya, D. Basu, S. Bhattacharya, S. Bhattacharya and K. Maitra. 2005. Melatonin accelerates maturation inducing hormone (MIH) induced oocyte maturation in carps. Gen. Comp. Endocrinol. 140:145-155.

Chattoraj, A., M. Seth and S. K. Maitra. 2009a. Localization and dynamics of melatonin receptor in the ovary of carp, Catla catla in relation to serum melatonin levels. Com. Biochem. Physiol. A, Mol. Integr. Physiol. 152:327-333.

Chattoraj, A., M. Seth, A. Basu, T. G. Shrivastava, S. Porta and S. K. Maitra. 2009b. Temporal relationship between the circulating profiles of melatonin and ovarian steroids under natural photothermal conditions in an annual reproductive cycle in carp Catla catla. Biol. Rhythm. Res. 40:347-359.

Delahunty, G. and M. Tomlinson. 1984. Hypoglycemic effects of melatonin in the goldfish, Carassius auratus. Comp. Biochem. Physiol. 78:871-875.

Delgado, M. J., P. Gutierrez and M. Alonso-Bedate. 1983. Effects of daily melatonin injection on the photoperiodic gonadal response of the female frog Rana ridibunda. Comp. Biochem. Physiol. 76:289-292.

De Pedro, N., R. Martinez-Alvarez and M. J. Delgado. 2008. Melatonin reduces body weight in goldfish (Carassius auratus): effects on metabolic resources and some feeding regulators. J. Pineal Res. 45:32-39.

Falcón, J., B. Laurence, S. Sandrine and B. Gilles. 2007. Melatonin effects on the hypothalamo-pituitary axis in fish. Trends Endocrinol. Metabol. 18(2):81-88.

Falcon, J., L. Besseau, M. Fuentes, M. Sauzet, E. Magnanou and G. Boeuf. 2009a. Structural and functional evaluation in pineal melatonin system in vertebrates. Ann. NY Acad. Sci. 1163: 101-111.

Falcon, J., H. Migaud, J. A. Munoz-Cueto and M. Carrillo. 2009b. Current knowledge on the melatonin system in teleost fish. Gen. Comp. Endocrinol. 165:469-482.

Fatemeh, M., M. Naderil and S. Adibi. 2007. Effects of melatonin on histopathological changes after experimental ovarian torsion- detorsion in cat. Iran. J. Reprod. Med. 5:177-181. 
Ghosh, J. and P. Nath. 2005. Seasonal effects of melatonin on ovary and plasma gonadotropin and vitellogenin levels in intact and pinealectomized catfish, Clarias batrachus (Linn). Ind. J. Exp. Biol. 43:224-232.

Guerrero, H. Y., E. Cardillo, G. Poleo and D. Macrcano. 2007. Daily and annual variations of plasma melatonin in the annual gonadal maturation. Proceedings of the $8^{\text {th }}$ international symposium on reproductive physiology of fish, Saint-Malo. 32: 22-24.

Joy, K. P. and A. K. Agha. 1991. Seasonal effect of administration of melatonin and 5- methoxy-trytophol on ovarian activity in the catfish Heteropneustes fossilis (Bloch). J. Pineal Res. 10: 65-70.

Koger, C. S., S. J. Teh and D. E. Hinton. 1999. Variations of light and temperature regimes and resulting effects on reproductive parameters in medaka (Oryzias latipes). Biol. Reprod. 61:1287-1293.

Lemer, A. B., J. D. Case, Y. Takahashi, Y. Lee and W. Mori. 1958. Isolation of melatonin, the pineal gland factor that lightens melanocytes. J. Am. Chem. Soc. 80:2587.

Lopez, L. F., J. A. Olmeda, F. J. Madrid and Sanchez-Vazquez. 2006. Melatonin effects on food intake and activity rhythms in two fish species with different activity patterns: Diurnal (goldfish) and nocturnal (tench). Comp. Biochem. Physiol. 144:180-187.

Lowry, O. H., N. J. Rosebrough, A. L. Farr and R. J. Randall. 1951. Protein measurement with folin's phenol reagents. J. Biol. Chem. 193:265-275.

Maitra, S. K., A. Chattoraj and S. Bhattacharyya. 2005. Implication of melatonin in oocyte maturation in Indian major carp Catla catla. Fish Physiol. Biochem. 31:201-207.

Maitra, S. K., R. Dey and S. Bhattacharya. 2001. Seasonal reproduction in fish: a functional interplay between the pineal organ and photoperiods. J. Endocrinol. Reprod. 5:1-12.

Mamdouh, M. A. and M. A. Abdel-Raheim. 2003. Oxidative stress in streptozotocin - induced diabetic rats: Effects of garlic oil and melatonin. Comp. Biochem. Physiol. Part A, 135:539-547.

Oppedal, F., J. E. Juell, G. L. Taranger and T. Hansen. 2001. Artificial light and season affect vertical distribution and swimming behaviors of post-smolt Atlantic salmon in sea cages. J. Fish Biol. 58:1570-1584.

Oppedal, F., G. L. Taranger and T. Hansen. 2003. Growth performance and sexual maturation in diploid and triploid Atlantic salmon (Salmo salar L.) in seawater tanks exposed to continuous light or simulated natural photoperiod. Aquaculture 215:145-162.

Paredes, S. D., A. Korkmaz, L. C. Manchester, D. X. Tan and R. J. Reiter. 2009. Phytomelatonin: a review. J. Exp. Bot. 60:57-69.

Pinillos, M. L., N. D. Pedro, A. L. Alonso-Gomez, M. AlonsoBedate and M. J. Delgado. 2001. Food intake inhibition by melatonin in goldfish (Carassius auratus). Physiol. Behav. 72:629-634.
Popek, W., E. Luszczek-Trojnar, E. Drog-Kozak, J. Rzsa and P. Epler. 2006. Effect of melatonin on dopamine secretion in the hypothalamus of mature female common carp, Cyprinus carpio L. Acta Ichthyol. Piscat. 36:134-141.

Porter, M. J. R., N. J. Duncan, D. Mitchell and N. R. Bromage. 1999. The use of cage lighting to reduce plasma melatonin in Atlantic salmon (Salmo salar) and its effects on the inhibition of grilling. Aquaculture 176:237-244.

Reiter, R. J., D. X. Tan and D. Acuna-Castroviejo. 2000. Melatonin: mechanisms and actions as an antioxidant. Curr. Top. Biophys. 24:171-183.

Renuka, K. and B. N. Josh. 2010. Melatonin-induced changes in ovarian function in the freshwater fish Channa punctatus (Bloch) held in long days and continuous light. Gen. Comp. Endocrinol. 165:42-46.

Shi Qiong. 2005. Melatonin is involved in sex change of the rice field eel, Monopterus albus Zuiew. Rev. Fish Biol. Fish. 15: 23-36.

Shulman, G. E. 1974. Life cycles of fish physiology and biochemistry. New York, Hulsted Press, John Wiley and sons.

Singh, A. K. 2009. Role of pineal melatonin during environmental sex determination in fishes. In: Recent advances in Hormonal Physiology of fish and Shell fish Reproduction (Eds. B. N. Singh and A. K. Pandey). Narendra Publishing House, New Delhi pp. 265-271.

Sokołowska, E., H. Kalamarz and X. Kulczykowska. 2004. Seasonal changes in brain melatonin concentration in the three-spined stickleback (Gasterosteus aculeatus): towards an endocrine calendar. Comp. Biochem. Physiol. Part A: Mol. Integr. Physiol. 13:365-369.

Sreenivasan, V., W. D. Spence, S. R. Pandi- Perumal, R. Zakharia, K. P. Bhatnagar and A. Brzezinski. 2009. Melatonin and human reproduction: shedding light on the darkness hormone. Gynecol. Endocrinol. 25:779-785.

Stein, E. A. 1986. Text book of clinical chemistry (Ed. N. W. Tietz). W. B Saunders Co. Philadelphia 1818-1829.

Sundararaj, B. I. and P. Keshavanath. 1976. Effects of melatonin and prolactin treatment on the hypophysial- ovarian system in the catfish, Heteropneustes fossilis (Bloch). Gen. Comp. Endocrinol. 129:84-96.

Tamura, H., Y. Nakamura, A. Korkmaz, L. C. Manchester and D. X. Tan. 2009. Melatonin and the ovary: physiological and pathophysiological implications. Fertil. Steril. 92:328-343.

Uraski, H. 1972. Effect of restricted photoperiods and melatonin: administration on gonadal weights in Japanese Kilifish. J. Endocrinol. 55:619-620.

Vanecek, J. 1998. Cellular mechanism of melatonin action. Physiol. Rev. 78:687-711.

Wang, Y., K. M. Peng, J. Li, H. Song, S. Heli, L. Wei and J. X. Wang. 2008. Ultrastructure and melatonin 1a receptor distribution in the ovaries of African ostrich chick. Cytotechnology 56:187-195.

Zhdanova, I. V., S. Y. Wang, O. U. Leclair and N. P. Danilova. 2001. Melatonin promotes sleep-like state in zebra fish. Brain Res. 903:263-268. 